\title{
ŞAŞIRTMALI MAHMUZLARIN ÜÇ BOYUTLU SAYISAL ANALİİ
}

\author{
Oğuz ŞiMŞEK*,Veysel GÜMÜŞ, Abdulkadir ÖZLÜK
}

Harran Üniversitesi, Mühendislik Fakültesi, İnşaat Mühendisliği Bölümü, Şanlıurfa, Türkiye

\begin{tabular}{|c|c|}
\hline Anahtar Kelimeler & Öz \\
\hline $\begin{array}{l}\text { Akışkan Hacimleri Yöntemi, } \\
\text { Sayısal Modelleme, } \\
\text { Su Yüzü Profili, } \\
\text { Saşırtmalı Mahmuz, } \\
\text { Üç Boyutlu Analiz. }\end{array}$ & $\begin{array}{l}\text { Mahmuzlar, kıyıda katı madde hareketini engelleyerek, kıyıların mevcut durumunu } \\
\text { korumak üzere inşa edilirler. Dalga hareketlerinin mevsimsel farklılık göstermesi, } \\
\text { kıyıların değişimine neden olabilmektedir. Kıyları korumak adına inşa edilen } \\
\text { mahmuzlarla etkileşim halinde olan akımın hareketinin analiz edilmesi, kıyıların } \\
\text { korunması açısından alınacak önemleri daha etkili kılacaktır. Bu çalışmada, farklı } \\
\text { akım durumlarında deneysel olarak incelenen şaşırtmalı mahmuzların üç boyutlu } \\
\text { sayısal modellemesi yapılmıştır. Sayısal modellemelerde, akımın hareketini } \\
\text { tanımlayan, Navier Stokes ve süreklilik denklemleri, sonlu hacimler yöntemi } \\
\text { kullanılarak çözülmüştür. Sayısal modellemelerde, türbülans viskozitesinin } \\
\text { hesabında, Ayrılmış Girdap Simülasyon (Detached Eddy Simulation-DES) modeli ve } \\
\text { su-hava arakesitinin belirlenmesinde ise akışkan hacimleri yöntemi kullanıllmıştır. } \\
\text { DES modeli kullanılarak elde edilen sayısal model sonuçları deneysel bulgularla } \\
\text { karşılaştırılmış ve karşılaştırma sonucunda sayısal model sonuçlarının deneysel } \\
\text { bulgularla oldukça uyumlu olduğu görülmüştür. Sonuç olarak, sayısal modelleme } \\
\text { tekniklerinin şaşırtmalı mahmuz yapılarıyla etkileşimde bulunan akım } \\
\text { problemlerinin çözümünde başarılı olduğu, farklı akım ve yapı koşullarında tekrar } \\
\text { edilebilme imkânı sunmasından dolayı tercih edilebileceği belirlenmiștir. }\end{array}$ \\
\hline
\end{tabular}

\section{THREE-DIMENSIONAL NUMERICAL ANALYSIS OF STAGGERED GROINS}

\author{
Keywords \\ Volume of Fluid Method, \\ Numerical Modeling, \\ Water Surface Profile, \\ Staggered Groins, \\ 3D Analysis.
}

\begin{abstract}
Groins are built to preserve the flow state of the coasts by impeding the movement of solids along the coast. The seasonal variation of wave movements can cause the coasts to change. Analyzing the movement of the flow in interaction with the groins, built to protect the coasts, will make the measures to be taken in terms of protection of the coasts more effective. In this study, three-dimensional numerical modeling of the staggered groins, which have been studied experimentally in different flow conditions, is made. In numerical models, Navier Stokes and continuity equations that govern the motion of the flow have been solved using the finite volume method. In numerical modeling, Detached Eddy Simulation (DES) model was used to calculate turbulent viscosity and Volume of Fluid (VOF) method is used to determine water-air intersection. The numerical model results obtained by using the DES model, are compared with the experimental findings. As a result of the comparison, it is found that the numerical model results were quite compatible with the experimental findings. As a result, it has been determined that numerical modeling techniques are successful in solving flow problems that interact with staggered groin structures. They can be preferred because it offers repeatability under different flow and structure conditions.
\end{abstract}

\section{Alıntı / Cite}

Şimşek, O., Gümüş, V., Özlük, A., (2021). Şaşırtmalı Mahmuzların Üç Boyutlu Sayısal Analizi, Mühendislik Bilimleri ve Tasarım Dergisi, 9(1), 187-198.

Yazar Kimliği / Author ID (ORCID Number)

O. Şimşek, 0000-0001-6324-0229

V. Gümüş, 0000-0003-2321-9526

A. Özlük, 0000-0002-0189-6203

\begin{tabular}{|l|}
\hline Makale Süreci / Article Process \\
Başvuru Tarihi / Submission Date \\
Revizyon Tarihi / Revision Date \\
Kabul Tarihi / Accepted Date \\
Yayım Tarihi / Published Date \\
\hline
\end{tabular}

01.12 .2020

31.01.2021

04.02.2021

30.03.2021

\footnotetext{
* ilgili yazar / Corresponding author: oguzsimsek@harran.edu.tr, +90-414-318-3000/3786
} 


\section{Giriş (Introduction)}

Mahmuzlar, kıyıda koruyucu bir alan oluşturmak amacıyla, kıyı şeridinde meydana gelen katı madde taşınımını ve erozyonunu önleyen, kıyıya dar ve dik olarak inşa edilen yapılardır. Mahmuzlar inşa edildikleri kıyıda, taşınan malzemeyi tutarak mevcut kıyının korunmasını sağlarlar. Ayrıca, yüksek plajlarda plajın ilk durumunu meydana getiren küçük çaplı sedimentlere göre daha iri sedimentlerin hareketlerini engelleyip, plajın yukarı kısımlarında biriktirilmesini sağlar ve memba tarafındaki malzeme hareketini azaltarak, akarsu veya denizlerde inşa edilen limanların ve balıkçı barınaklarının bu taşınan malzemeyle dolmalarını önleyerek işlevlerini sağlamak ve korumak gibi amaçlar için inşa edilirler. Mahmuzlar şekline göre düz mahmuzlar, T ve L mahmuzlar, inşasında kullanılan malzeme cinsine göre ise ahşap, çelik, beton ve taş mahmuzlar, işlevine göre ise kısmen geçirimsiz ve tamamen geçirimsiz mahmuzlar, yüksekliğine göre yüksek ve alçak mahmuzlar, sabit ve yüksekliğinin yanında açısı değişken (ayarlanabilir) mahmuzlar şeklinde sınıflandırılırlar (Özölçer vd, 2006; Süme ve Yüksel, 2018; Süme vd, 2019).

Mahmuzlar, genellikle akarsu yatağında mendereslerin ve kıvrımların bulunduğu bölgelerde, iç kıyıda katı madde yığılmasını dış kıyıda ise kıyı aşınmasını önlemek üzere inşa edilirler. Hareket halindeki katı maddenin hareketine, mahmuzların boyları, aralıkları, tipleri ve akımla olan açıları etki etmektedir. Ülkemizin üç tarafının denizlerle çevrili olmasından dolayı kıyılarımızın korunması ve kıyı tahribatının önlenmesi oldukça önemli bir konu olarak karşımıza çıkmaktadır. Çok sayıda araştırmacı tarafından fiziksel ve sayısal model çalışması yapılmakta ve kıyıların mevcut durumlarının korunması ve gerekli tedbirlerin alınması açısından öneriler geliştirilmektedir (Özölçer, 1998; Süme, 2014). Hanson ve Kraus (1990), dalga kıran ve mahmuzların kıyı şeridine olan etkilerini belirlemek için deneysel ve sayısal modelleme gerçekleştirmişlerdir. Deneysel ve sayısal modellemelerde, dalgalar akıma eğik bir açıyla gönderilerek kıyı, harekete zorlanmıştır. Deneysel ve sayısal model sonuçlarından, mahmuzlar ve dalgakıranlarla etkileşimde olan dalgalanın akım karakteristiklerinin benzer olduğu belirtilmiştir. Sayısal model sonucunda elde edilen sediment taşınım kalibrasyon katsayısının, kıyı yapıları için oluşturulan prototip modellerinde uygun görülen katsayı aralığında olduğu görülmüştür. Çalışma sonucunda, fiziksel modellerin, kıyılara inşa edilen yapıların, kıyı şeridi üzerindeki etkisinin zamansal ve uzamsal özelliklerini doğru bir şekilde ölçeklenebildiği belirlenmiştir. Abam (1993), Nijer Deltasındaki erozyunu kontrol etmek için kullanılacak yöntemleri deneysel olarak incelemiștir. Yöntem olarak güçlü kamıș ağları ile bağlanmıș ahșap yığınlar kullanılarak geçirgen bir mahmuz tasarlamıştır. Yağışların gerçekleştiği dönemde, ana kanal içerisindeki akımın mevsimin pik değerlerinin \%10 seviyesine ulaşması durumunda yerel kaymaların meydana geldiğini ve mahmuzlarda arızaların oluștuğunu tespit etmiştir. Yaptığı deneylerin sonucunda, kazık sisteminin gömülme derinliğinin mahmuz yapısının stabilizesini sağlayan en önemli faktör olduğunu ortaya çıkarmıștır. Badiei vd. (1995), mahmuzların kıyıya olan etkisini belirlemek üzere deneysel çalışmalar yapmışlardır. Mahmuzsuz ve farklı geçirimliliğe sahip mahmuzlu olmak üzere, farklı sahil uzunluklarında model çalışmaları gerçekleştirilmiştir. Sonuçta, sayısal model çalışmalarının test edilmesi ve doğruluğunun kontrol edilmesi için önemli bilgilerin elde edildiği belirtilmiştir. Deneysel olarak elde edilen bulguların değerlendirilmesinden, sahil batimetrisinin ve morfolojisinin analiz açısından önemli olduğu görülmüsstür. Yllmaz (2003), derinlik ortalamalı sığ su denklemlerinin sonlu hacimler metoduyla değişken ve iki boyutlu akım için çözüm algoritmasını geliştirmek üzere araştırma yapmıştır. Geliştirilen çözüm algoritmasının doğruluğunun test etmek için literatürde bulunan mevcut bulguları ve laboratuvar ölçümlerini kullanmıștır. Deneysel çalışmada, iki ve üç boyutlu olmak üzere farklı akım türlerini incelemiștir. Üç boyutlu akım problemi için kanal yan yüzeylerine dikdörtgen mahmuzlar yerleștirilerek, bu yapılar ile etkileşim halinde olan akımı analiz etmişlerdir. Deneysel ve sayısal sonuçların karşılaştırılmasından, iki boyutlu akım probleminin çözümde bu çözüm algoritmasının kabul edilebilir olduğu, üç boyutlu akım probleminin çözümde ise iyileștirme yapılması gerektiğini ve uygun bir türbülans modeliyle daha iyi sonuçlar elde edileceği belirtilmiștir. Gu ve Ikeda (2009), açık kanal içerisine farklı sayıda mahmuz yerleștirmiș ve farklı mahmuzlar ara mesafesinde mahmuzlarla etkileşimde olan akımı deneysel olarak analiz etmişlerdir. Deneysel olarak elde edilen sonuçlardan, akım alanında maksimum hızın mahmuzların mansap bölgesinde mahmuzlar arasındaki mesafenin $2 / 5$ olduğu durumda oluştuğu ve yeniden bağlanma noktalarının mahmuzlar arasındaki mesafenin 4/5 olduğu durumda oluştuğu tespit etmişlerdir. Ayrıca, $x$ doğrultusundaki akış yönü ile akış arasındaki açının mahmuzlar arasındaki mesafenin artmasıyla azaldığını belirtmişlerdir. Barcelo (2014) yüksek ve geçirimsiz mahmuzların hidrolik davranışlarını incelemek için deneysel olarak çalışmıştır. Deneysel çalışmada farklı dalga özellikleri kullanarak sahilde meydana gelecek değişikleri belirlemek ve bu değişiklikleri kontrol altına almak üzere mahmuz inşa edilmesinin etkisini belirlemeyi hedeflemiştir. Ayrıca, dalga hareketinin karakteristikleriyle kıyı boyu akıntı arasında ilişki kurmayı amaçlamıştır. Mahmuzların kullanılmasıyla bir bölgede belli bir zaman aralığında biriken katı madde miktarının hesaplanabileceği ve bu değerin kullanılarak kıyı boyu akıntı miktarının belirlenebileceği belirtilmiștir. Çalışma sonucunda, gönderilen dalganın gücü ile kıyı boyu akıntısı arasında doğrudan ilişki olduğu belirlenmiştir. Safie ve Tominaga (2020), farklı kazık grubu mahmuzların akış yavaşlaması üzerindeki etkileri deneysel olarak araştırmıştır. Kazık yoğunluğu, düzenleme, sıra aralığı ve uzunluğun akım üzerindeki etkilerinin belirlenmesi için çok sayıda deneysel çalışma yapılmıștır. Kazıkların yerleștirilme şeklinin ve düzeninin, mahmuzların arkasındaki akış büyüklüğünün ve modelin kontrolünde etkin bir parametre olduğu 
belirlenmiş ve farklı sayıda ve düzende kazık yerleștirilerek, etkin akım hızında kademeli ve yumuşak bir hız düşüşü elde edilebileceği sonucuna ulaşılmıştır. Mevcut literatür incelendiğinde, mahmuzlarla ilgili sayısal modellemenin yapıldığı çalışmaların yeteri sayıda olmadığı ve sayısal model sonuçlarının deneysel sonuçlarla doğrulanması çalışmasının yapılmadığı söylenebilir. Farklı hidrolik yapıların sayısal modellemesinin yapıldığı çalıșmaların sonuçları, sayısal modellemelerin yapı akım etkileșimi problemlerin çözümünde, akım alanında ayrılmaların ve ikincil akımların bulunduğu akımların çözümünde güvenle kullanılabileceğini göstermektedir (Rogallo ve Moin, 1984; Aköz vd, 2007; Kırkgöz vd, 2009; Aköz vd, 2009; Öner, 2009; Şimşek, 2020a; Şimşek, 2020b). Bu alandaki çalışmaların çoğaltılmasına gereksinim olduğu düşünülmektedir.

Bu çalışmada, Yılmaz (2003) tarafından laboratuvar ortamında farklı akım durumları için gerçekleştirilen fiziksel modelin 3 boyutlu sayısal modellemesi yapılmıștır. Akımı hareketini yöneten süreklilik ve momentum denklemleri, sonlu hacimler yöntemine dayalı çözüm yapan ANSYS- Fluent paket programıyla çözülmüştür. Su yüzü profilinin sayısal olarak elde edilmesinde ise Akışkan Hacimleri Yöntemi (Volume of Fluid-VOF) kullanılmıştır. Türbülans viskozitesinin sayısal modellenmesinde ise, üç boyutlu karmaşık akım yapılarını modellemesinde oldukça başarılı olan (Aköz vd, 2016; Jesudhas vd, 2017; Jesudhas, 2020) Detached Eddy Simülasyon (DES) modeli tercih edilmiştir. Farklı akım durumunda elde edilen enine ve boyuna deneysel su yüzü profilleri, sayısal olarak elde edilen su yüzü profilleriyle karşılaştırılmıştır. Deneysel olarak elde edilmesi için basınç sensörleri, hız ve seviye ölçüm aletleri gibi özel ekipman ve uzman kişiler gerektiren akımla ilgili bazı parametreler, sayısal modelleme sonucunda elde edilmiş ve değerlendirilmiştir.

\section{Deneysel Çalışma (Experimental Study)}

Deneyler, Yılmaz (2003) tarafından, Orta Doğu Teknik Üniversitesi (ODTÜ) İnșaat Mühendisliği Bölümü Hidrolik laboratuvarındaki, $12 \mathrm{~m}$ uzunluğunda, 0,67 m genişliğinde ve 0,50 m derinliğinde, yan duvarları camdan, tabanı ise hidrolik olarak cilalı olarak kabul edilen pleksiglastan tasarlanmış açık kanal modelinde yürütülmüştür Mahmuzlar dikdörtgen geometriye sahip olup kanal en kesiti boyunca uzunluğu 0,25 m, kanal boyunca uzunluğu 0,10 m olarak belirlenmiştir (Şekil 1). İlk mahmuz kanal başlangıcından 1,2 m ileriye yerleștirilmiş olup karşı kenardaki mahmuz ile arasında 0,60 m mesafe bulunmaktadır. Aynı kenarda bulunan mahmuzlar arasında 1,2 m mesafe olacak șekilde yerleștirilmiștir. Deney kanalının tamamı kullanılmamıș olup sadece 3,1 m uzunluğunda bir bölgeye, 4 adet mahmuz şaşırtmalı olarak yerleştirilmiștir (Şekil 2). Akım debisinin 0,02 m³/s (A1), 0,04 m³/s (B1) ve 0,06 (C1) $\mathrm{m}^{3} / \mathrm{s}$ olduğu durumlarda, kanal orta ekseninde boyuna ve belirli aralıklarla enine su yüzü profilleri deneysel olarak elde edilmiştir. Akımın düzensiz olmasından kaynaklı olarak, maksimum ve minimum su derinlikleri ayrı ayrı ölçülmüştür. Kanal uzunluğu boyunca 0,1 m aralıklarla yerleştirilen 28 adet istasyondan, kanal en kesiti boyunca ise 0,03 m aralıklı 23 adet farklı istasyondan derinlik ölçümleri yapılarak, kanal boyuna ve enine su yüzü profilleri elde edilmiştir. Bir akım profilinin deneysel olarak belirlenmesi için toplamda 644 adet ölçüm değeri kullanılmıştır. Ayrıca, su yüzü profilleri serbest veya batık durumda elde edilmiştir (Yılmaz, 2003)

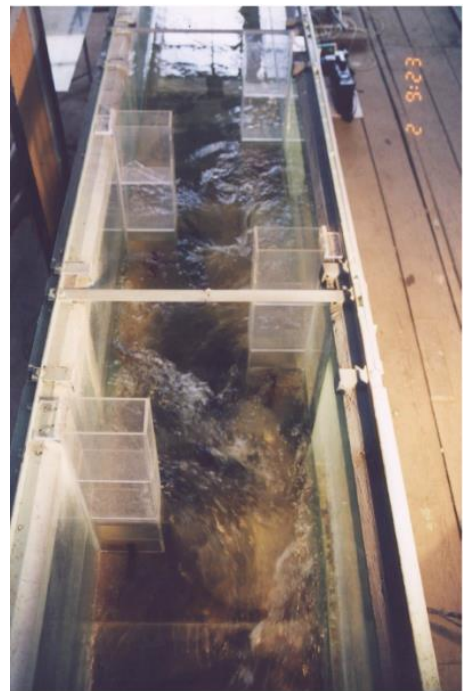

Şekil 1. Deney düzeneği (Experimental setup) (Yılmaz, 2003) 


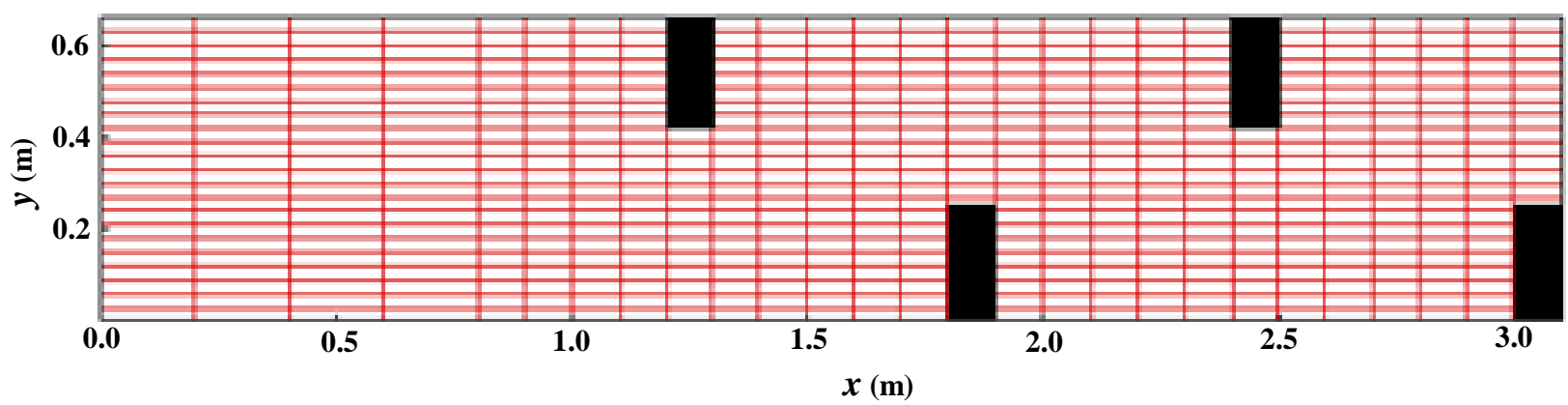

Şekil 2. Mahmuzların şematik gösterimi (Schematic view of groins) (Yılmaz, 2003)

\section{Sayısal Modelleme (Numerical Modeling)}

\subsection{Temel Denklemler (Basic Equations)}

Üç-boyutlu, sıkışmayan ve türbülanslı açık kanal akımının hareketini idare eden temel denklemler, kütlenin ve momentumun korunumu (Reynolds-ortalamalı Navier-Stokes) denklemleri sırasıyla aşağıdaki gibidir:

$$
\begin{aligned}
& \frac{\partial \bar{u}_{i}}{\partial x_{i}}=0 \\
& \rho\left(\frac{\partial \bar{u}_{i}}{\partial t}+\bar{u}_{j} \frac{\partial \bar{u}_{i}}{\partial x_{j}}\right)=\rho g_{i}-\frac{\partial \bar{p}}{\partial x_{i}}+\mu \frac{\partial^{2} \bar{u}_{i}}{\partial x_{j}^{2}}+\frac{\partial \tau_{i j}}{\partial x_{j}}
\end{aligned}
$$

(1) ve (2) denklemlerinde $u_{\mathrm{i}}, x_{\mathrm{i}}$ doğrultusundaki hız bileșeni, g yer çekimi ivmesi, $p$ basınç, $\mu$ dinamik viskozite, $\rho$ akışkan yoğunluğu ve $\tau_{i j}$ türbülans (Reynolds) gerilmeleridir. Bu çalışmaya konu olan üç boyutlu akımı idare eden yukarıdaki 4 adet denklem 10 adet bilinmeyen içermektedir, bunlar: üç hız bileșeni $\bar{u}_{i}$, basınç $\bar{p}$ ve 6 bağımsız Reynolds gerilmesidir ( $\left.-\rho \overline{u_{i}^{\prime} u_{j}^{\prime}}\right)$. Böylece, denklem sisteminin çözülebilmesi için türbülans gerilmelerinin tanımlanmasına ihtiyaç duyulmaktadır. Bu sorun, yukarıdaki zamansal-ortalama denklemlerin sayısal çözümü sürecinde, denklemlerde yer alan türbülans gerilmelerinin uygun türbülans kapatma modelleriyle tanımlanmasını gerektirmektedir. Türbülans viskozitesinin doğrusal olarak ifade edilmesini esas alan Boussinesq yaklaşımına göre (2) denklemindeki türbülans kayma gerilmeleri bünye denklemi ile, sıkışmayan akımlar için aşağıdaki gibi verilmiştir:

$$
\tau_{i j}=-\rho \overline{u_{i}^{\prime} u_{j}^{\prime}}=\mu_{t}\left(\frac{\partial \bar{u}_{i}}{\partial x_{j}}+\frac{\partial \bar{u}_{j}}{\partial x_{i}}\right)-\frac{2}{3} \rho k \delta_{i j}
$$

burada $u_{i}^{\prime}$ ve $u_{j}^{\prime}$ yatay ve düşey türbülans hız sapınçları, $\mu_{t}$ türbülans viskozitesi, $k\left(=\overline{u_{i}^{\prime} u_{i}^{\prime}} / 2\right)$ türbülans kinetik enerjisi ve $\delta_{i j}$ Kronecker deltasıdır.

\subsection{Türbülans Modeli (Turbulence Model)}

Denklem (3)'de görülen $\mu_{t}$ türbülans viskozitesinin hesaplanmasında birçok türbülans kapatma modeli farklı araştırmacılar tarafından geliştirilmiştir. Bu çalışmada, $\mu_{t}^{\prime}$ nin hesabında DES modeli kullanılmıştır. DES modeli, Large Eddy Simulation (LES) ve Reynolds Ortalamalı Navier Stokes (RANS) modellerinin birleştirilmesi sonucunda elde edilmiş hibrit bir modeldir. Bu model, LES ve RANS modellerini yüksek Reynolds sayıll, harici aerodinamik simülasyonlarının mevcut olduğu uygulamalar için birleștirmektedir. ANSYS-Fluent paket programı, DES için dört farklı alt model önermektedir. Bunlar, Spalart-Allmaras, Realizable $k-\varepsilon$, SST $k-\oplus$ ve Transition SST modelleridir (ANSYS, 2012). DES modelinin hesaplama maliyeti, RANS modellerine göre daha fazla iken, LES modeline klyasla daha azdır. Bu çalışmada, DES ile yapılan sayısal hesaplamalarda Realizable $k$ - $\varepsilon$ alt modeli kullanılmıştır. DES modeli köprü ayağının mansap bölgesinde ve batmış hidrolik sıçrama gibi dinamik yapının bulunduğu akım problemlerinin çözümünde oldukça başarılı sonuçlar vermektedir (Aköz vd, 2016; Jesudhas vd, 2017; Jesudhas, 2020). 


\subsection{Akışkan Hacimleri Yöntemi (Volume of Fluid Method- VOF)}

Sayısal modellemelerde, birbirine karışmayan en az iki farklı akışkanın birbiriyle etkileşimde olduğu ara yüzeyinin belirlenmesinde, akışkan hacimler yöntemi oldukça sık kullanılmaktadır (Kirkgoz vd., 2008; Kirkgoz vd., 2009; Muslu, 2001; Aydın ,2012; Soydan vd., 2012; Akoz vd., 2014; Simsek vd., 2016; Soydan vd., 2017; İlkentapan ve Öner, 2017; Gümüş vd., 2018; Soydan vd., 2020; Şimşek, 2020a; Şimşek,2020b). Bu yöntemde hesaplama ağının her bir hücresinin hacimsel doluluk oranını temsil eden $\mathrm{F}$ akışkan hacmi tanımlanır. F değeri, hücrenin tamamen dolu olması durumunda 1, kısmı dolu olması durumunda 0 ile 1 arasında veya tamamen boş olması durumunda ise 0 değerini almaktadır (Hirt ve Nichols, 1981). Serbest su yüzünün hesaplanmasında akışkan hacimleri yönteminde "Geo-Reconstruct" yaklaşımı tercih edilmiştir (ANSYS, 2012). Geo-Reconstruct yaklaşımında, ilk olarak tamamen dolu veya boş olmayan her bir hücrenin doluluk oranı ve onun türevleriyle bağlantılı bilgiler kullanılarak, su-hava doğrusal ara kesitinin hücre ağırlık merkezine göre yeri tespit edilir. Daha sonra, elde edilen doğrusal ara kesitin yeri ve hücre yüzeylerinde elde edilmiş normal ve teğetsel hız değerleri yardımıyla her bir hücrenin yüzeyinden taşınan akıșkan miktarı elde edilir. Son olarak, ikinci adımda hesaplanan akışkan miktarları dikkate alınarak, süreklilik denklemi ile her bir hücrenin hacimsel doluluk oranı hesap edilir. Temsili olarak suhava arakesitinin doluluk oranını gösteren örnek bir görüntü Şekil 3'te verilmiştir. Şekil üzerindeki sayısal değerler, kesitteki F doluluk oranlarının sayısal değerlerini göstermektedir.

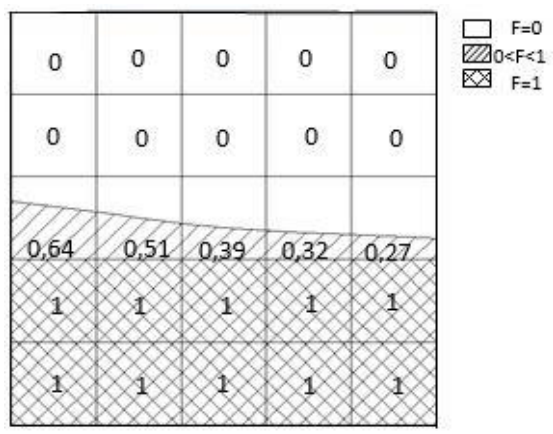

Şekil 3. Ağ elemanlarının doluluk oranı (Occupancy rate of computational grid)

\section{4. Çözüm Bölgesi, Başlangıç ve Sınır Şartları (Solution Domain, Initial and Boundary Conditions)}

Şekil 4'te, sayısal modellemelerde kullanılan çözüm bölgesi ve sınır şartları verilmiştir. Sayısal modellemelerde kullanılan koordinat sisteminin orijini, çözüm bölgesinin sol alt köşesi olarak alınmıştır. Çözüm bölgesinin giriş sınırının üst kısmı (G), üst (D) ve çıkış sınırlarının (A) sınır şartları sıfır basınç ( $p=0$ ), kanal tabanında (F) ve mahmuz yüzeylerinde ( $C$ ve $E$ ) sıfır hız sınır şartı, yani $u=0, v=0$ olarak tanımlanmıştır. $A 1$, B1 ve $C 1$ akım durumlarında sayısal modelde giriş sınır (B) şartı olarak yatay hız bileşeni deneysel debi değerlerinden elde edilen akım hızları sırasıyla $0,23,0,267$ ve $0,298 \mathrm{~m} / \mathrm{s}$ olarak ve düșey hız bileșeni ise $\mathrm{v}=0$ olarak tanımlanmıștır. Zamana bağlı çözüm sürecinde, başlangıç şartı olarak, çözüm bölgesinin giriş sınırında doluluk oranı $F=1$, diğer bölgeler ve çözüm bölgesinin çıkış sınırında ise $\mathrm{F}=0$ alınmıştır. Ayrıca, giriş sınırında, hidrolik çap A1, B1 ve C1 akım durumlarında sırasıyla $0,44,0,5508,0,622$ m ve türbülans şiddeti tüm akım durumlarında $\% 5$ olarak alınmıştır.

Sayısal modellemede kullanılan DES modeli için zaman adımı değişken olarak seçilmiştir. Courant sayısının maksimum 2 olacak şekilde zaman adımı kullanılan paket program tarafından hesaplanmıștır. Sayısal çözümler, akım dengeye geldikten sonra yaklaşık olarak 30s daha devam ettirilmiştir. Toplamda hesaplama süresi 50s olarak belirlenmiştir.

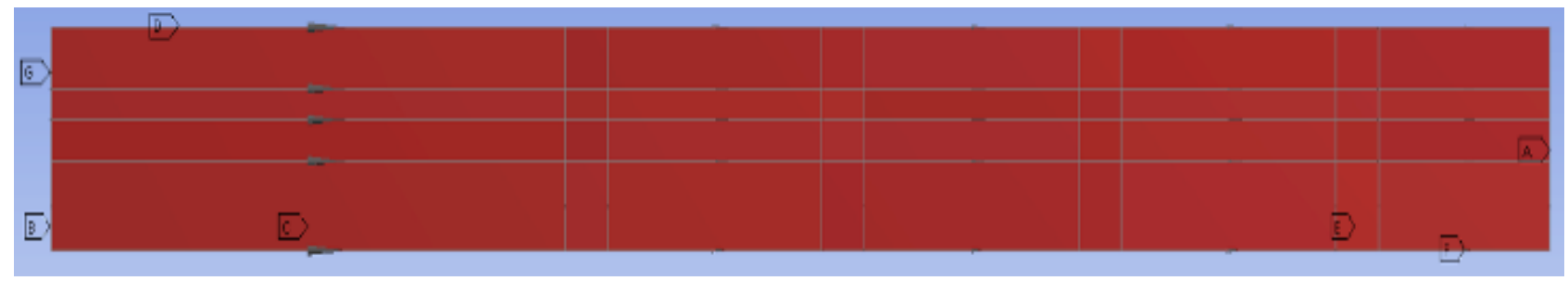

Şekil 4. Çözüm bölgesi ve sınırlar (Solution domain and boundaries) 


\subsection{Sayısal Hesaplama Ă̆ı Tasarımı (Design of Numerical Computational Grid)}

Sayısal modellemelerde kullanılan hesaplama ağının sonuçlar üzerindeki etkisi, sayısal modelleme konusunda çalışan araştırmacılar tarafından bilinmektedir. Bu çalışmada, sayısal modellemede üç farklı akım durumunda aynı hesaplama ağının kullanılması için giriș sınırı dört alt bölgeye ayrılarak giriş su yüksekliklerine bağlı olarak sınır şartları değiștirilmiştir. C1 akım durumunda elde edilen su yüksekliğinin üzerinde $0.05 \mathrm{~m}$ mesafe bırakılarak suhava arakesitinin program tarafından doğru bir şekilde belirlenmesi amaçlanmıştır. Çözüm bölgesi planda 23 alt bölgeye, yandan 36 alt bölgeye ayrılarak toplamda 828 alt bölge oluşturulmuştur (Şekil 5). Mahmuzların şaşırtmalı olması, alt bölge sayısının artmasına neden olmasına karşın hesaplama ağının dikdörtgen elemanlardan oluşması sağlanmıştır. Çözüm bölgesinin tamamında yaklaşık olarak 3200000 tane dikdörtgen eleman bulunmaktadır.
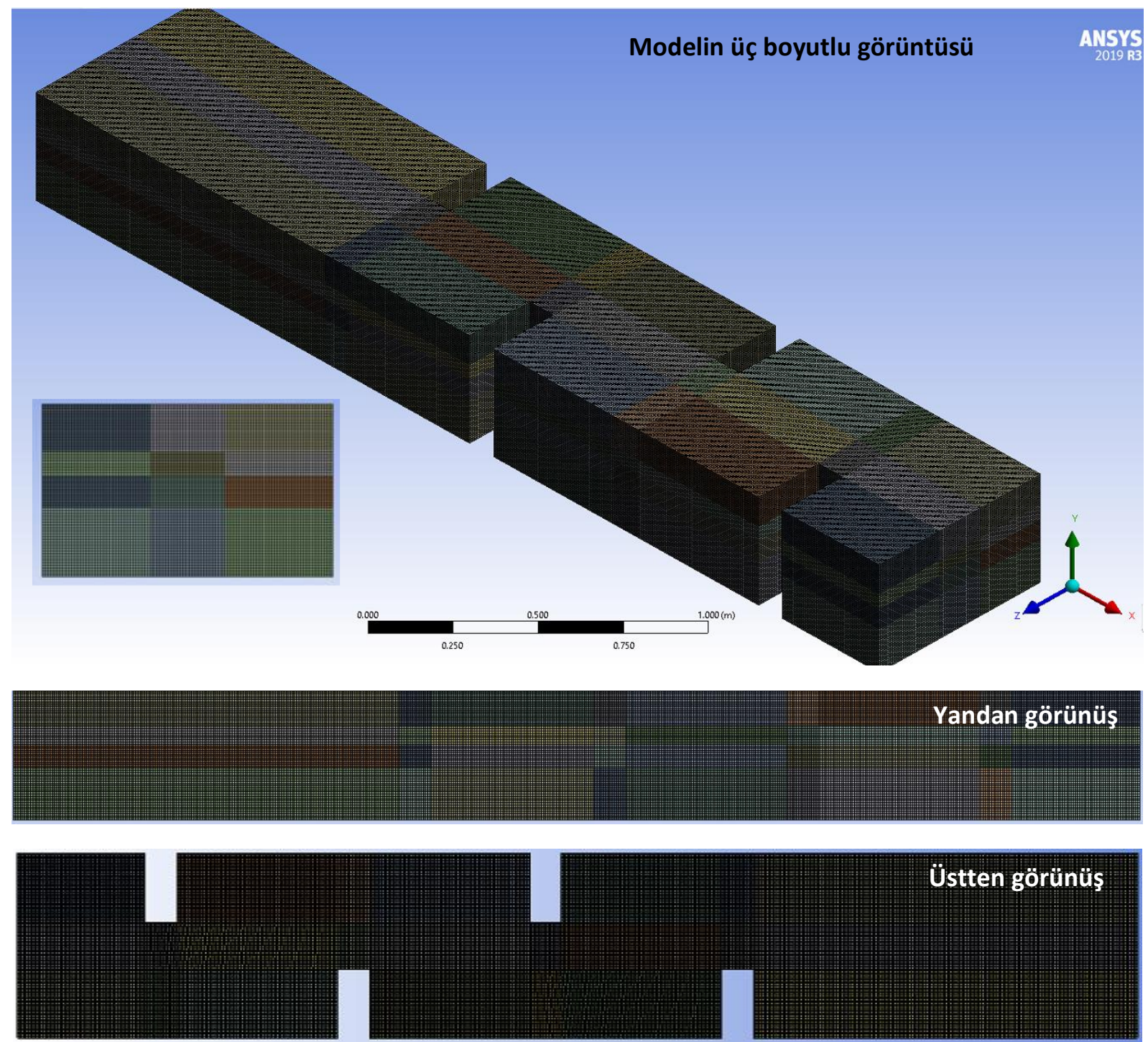

Şekil 5. Sayısal hesaplama ağı (Numerical computational grid)

\section{Bulgular ve Tartışma (Results and Discussion)}

\subsection{Deneysel ve Sayısal Su Yüzü Profilleri (Experimental and Numerical Water Surface Profiles)}

Yılmaz (2003) tarafından, A1 serbest akım durumda deneysel olarak elde edilen su yüzü profillerinin sayısal model sonuçları ile karşılaştırılması Şekil 6'da verilmiştir. Şekil 6 incelendiğinde, kanal orta kesitinde x ekseni boyunca elde edilen deneysel ve sayısal su yüzü profillerinin oldukça uyumlu olduğu görülmektedir. Kanal en kesitinde farklı x mesafelerinde elde edilen deneysel ve sayısal su yüzü profillerinin birbiriyle benzer olduğu söylenebilir. Kanal sonuna doğru akımın daha karmaşık hale geldiği x=3m en kesitinde elde edilen su yüzü profillerinin diğer en kesitlerden elde edilenlere kiyasla daha uyumsuz olduğu görülmekte ise de bu kesitte genel olarak su yüzü profilinin birbiriyle benzer olduğu ifade edilebilir. 
Akım debisinin A1 durumuna kıyasla iki kat arttı̆̆ B1 durumunda elde edilen deneysel su yüzü profillerinin, sayısal model sonuçlarıyla karşılaştırılması Şekil 7'de verilmiştir. Kanal orta ekseninde elde edilen su yüzü profilinin ve $\mathrm{x}=0,1,1.5,2,2.5$ ve $3 \mathrm{~m}$ kesitlerinde elde edilen deneysel su yüzü profillerin sayısal su yüzü profilleriyle arasındaki uyumun oldukça iyi olduğu görülmektedir. A1 durumuna benzer olarak sayısal ve deneysel su yüzü profilleri arasında $\mathrm{x}=3 \mathrm{~m}$ kesitinde çok az da olsa kanal orta bölgesinde farklılık bulunduğu söylenebilir. Bu uyuşmazlığın, bu kesitin kanal çıkış kesiti olması, akımın bu kesite gelinceye kadar mahmuz yapılarıyla etkileşimde olması nedeniyle akımın karmaşık bir yapı sergilemesinden kaynaklandığı düşünülmektedir.
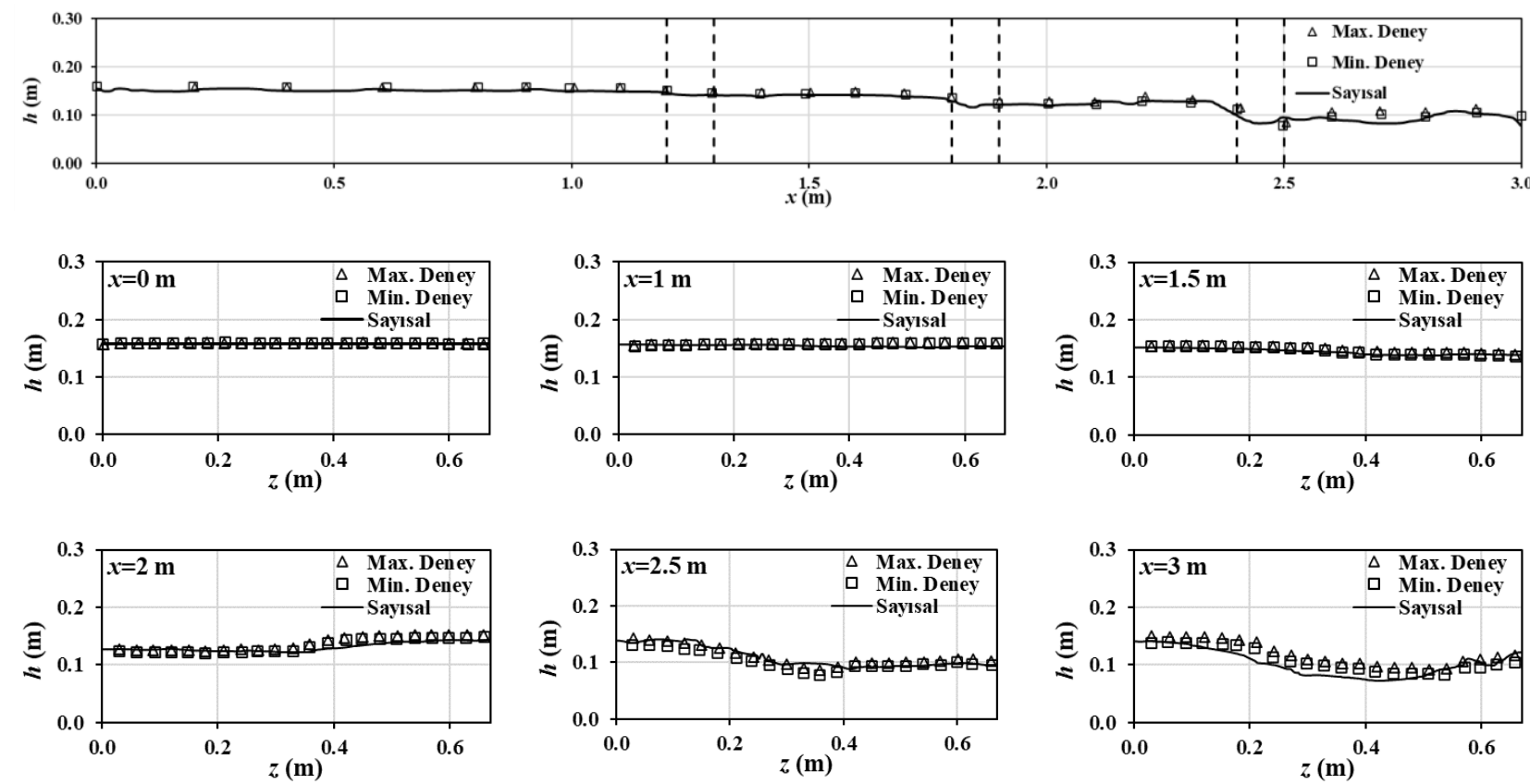

Şekil 6. Deneysel ve sayısal su yüzü profillerinin karşlaştırılması (A1) (Comparison of experimental and numerical water surface profiles (A1))
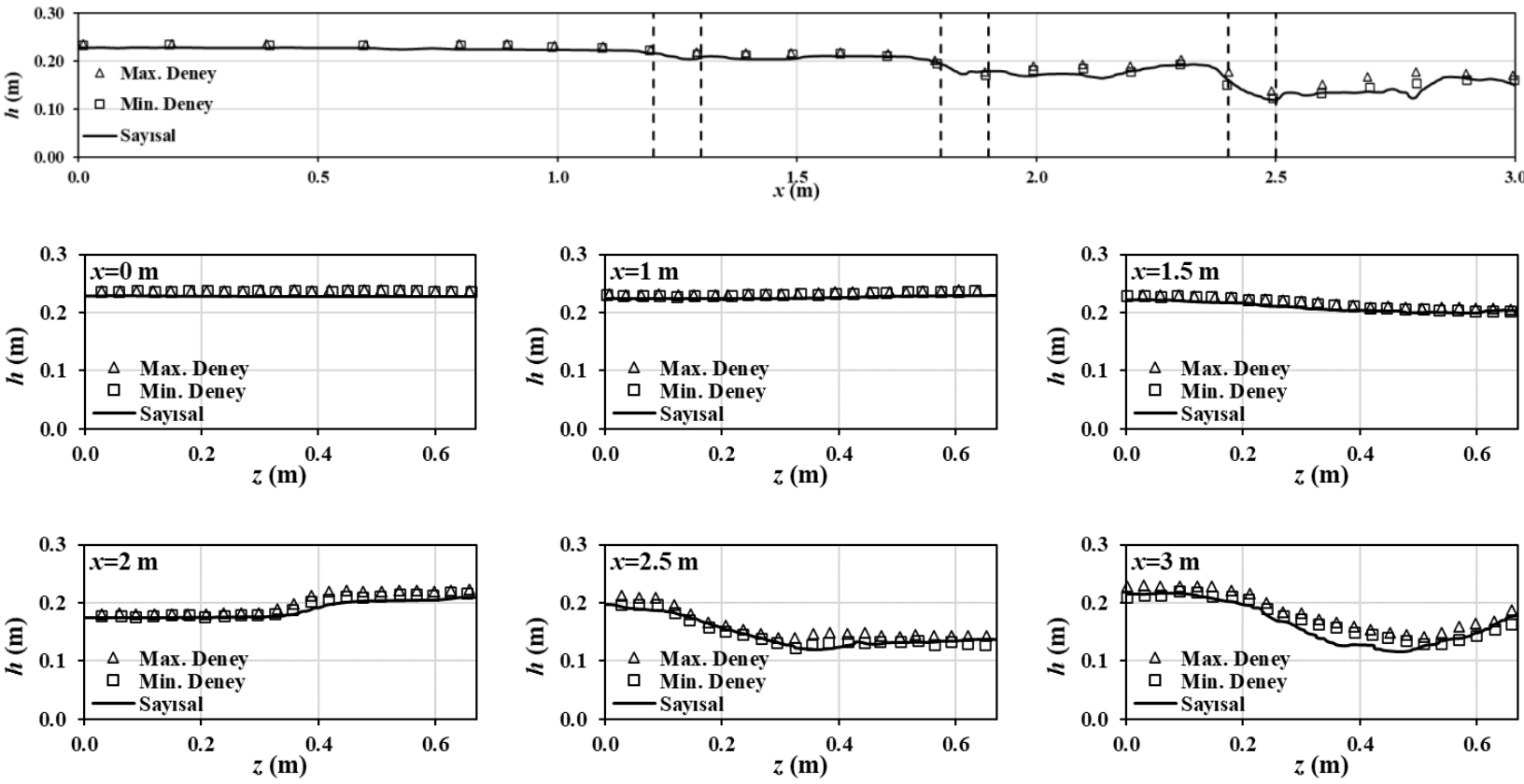

Şekil 7. Deneysel ve sayısal su yüzü profillerinin karşılaştırılması (B1) (Comparison of experimental and numerical water surface profiles (B1))

Şekil 8'de, C1 serbest akım durumunda deneysel ve sayısal olarak elde edilen su yüzü profillerinin karşlaştırılması verilmiştir. Kanal orta ekseninde x doğrultusu boyunca elde edilen profillerin birbiriyle genel olarak uyumlu olduğu görülmektedir. Akım debisinin artmasıyla $x=2.5$ ve $3 \mathrm{~m}$ kesitlerinde elde edilen su yüzü profilleri arasında uyumsuzluğun arttığı belirtilebilir. Bu duruma akım debisinde artıştan kaynaklı olarak akımda meydana gelen 
düzensizliğin A1 ve B1 durumlarına göre daha büyük olması gösterilebilir. Bu bölgedeki su yüzünde meydana gelen değişim diğer debi durumlarına kıyasla daha büyük olmaktadır. Tüm akım durumlarında kanal boyunca elde edilen su yüzü profillerinde, akımın mahmuzlarla etkileşimde bulunduğu bölgelerde akım hızında meydana gelen azalıș veya artıştan dolayı memba ön bölgesinde su derinliğinin arttığı ve mahmuzların bulunduğu kesitte su derinliğinin azaldı̆̆ı görülmektedir.
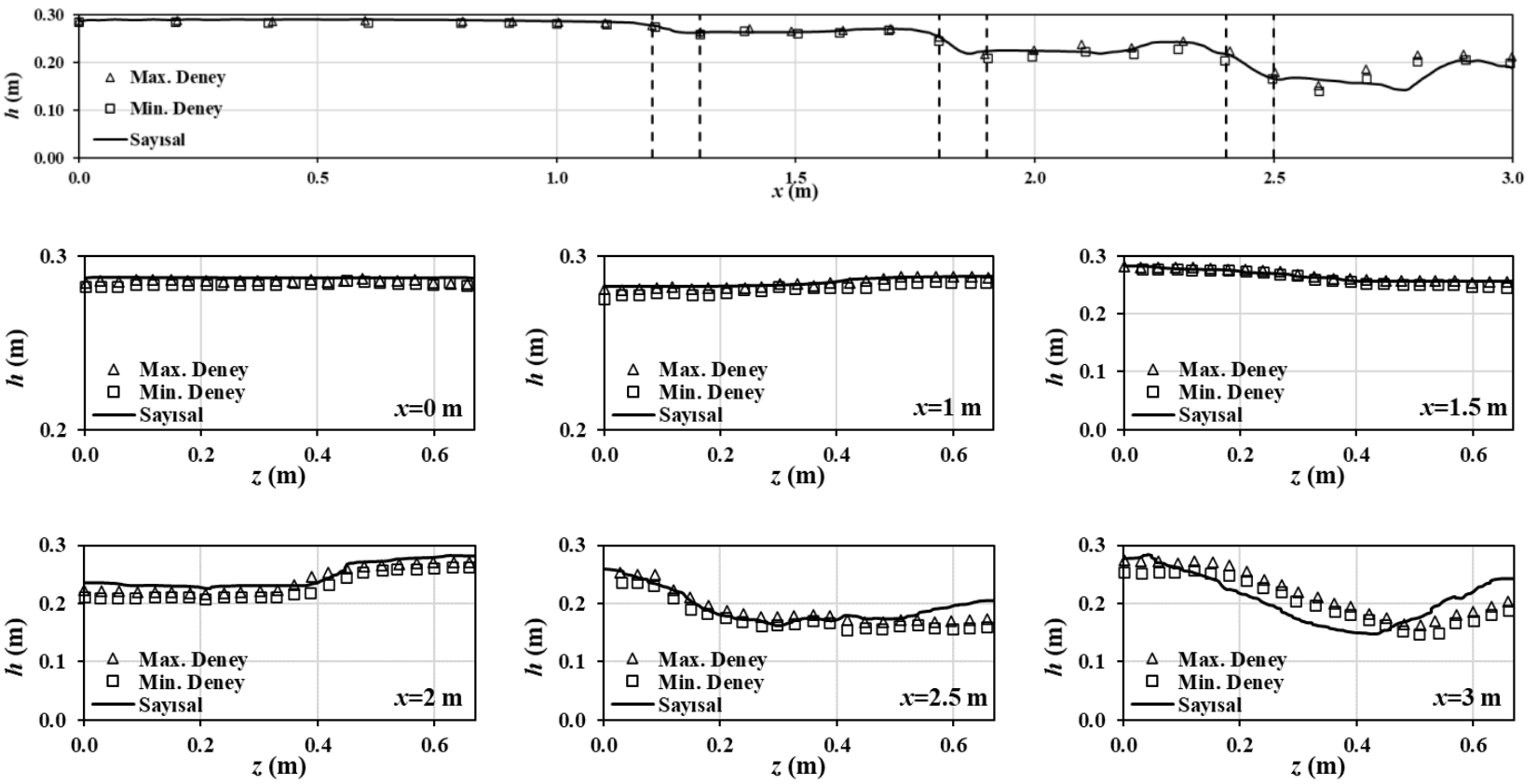

Şekil 8. Deneysel ve sayısal su yüzü profillerinin karşılaştırılması (C1) (Comparison of experimental and numerical water surface profiles (C1))

\subsection{Sayısal Hız Alanı (Numerical Velocity Field)}

Farklı akım durumlarında x ekseni boyunca farklı kesitlerde elde edilmiş ortalama bileşke hızların dağılımları Şekil 9'da verilmiştir. A1, B1 ve C1 akım durumunda, $\mathrm{x}=2,5 \mathrm{~m}$ ve $3 \mathrm{~m}$ kesitlerinde kanal orta ekseninde oluşan hız değerlerinin sırasıyla $1.2 \mathrm{~m} / \mathrm{s}, 1,6 \mathrm{~m} / \mathrm{s}$ ve 1,7 m/s şeklinde olduğu görülmektedir. Kıyıların korunmasında aktif rol oynayan mahmuzların, akım kesit alanını daraltmasından kaynaklı olarak kanal orta eksende artan hızların oluştuğu bölgede, yatak malzemesinin korunması gerekli olduğu ortaya çıkmaktadır. Hızı artan akımın, sürükleme kuvvetinin artmasına paralel olarak yatak malzemesinde aşınma ve oyulma hızlanacaktır. Bunun yanında, aşınma ve oyulmanın aşırı büyümesi sonucunda menfezlerin statik dengesinde sorunlar yaşanabilecektir.

A1, B1 ve C1 akım durumlarında farklı kanal en kesitinde akım doğrultusundaki hız bileşenin dağılımı Şekil 10'da verilmiştir. Şekil incelendiğinde, oluşan dağılımın Şekil 9'da verilen dağılıma benzer olduğu görülmektedir. Elde edilen grafiklerden akım debisinin artmasıyla birlikte x doğrultusundaki hız değeri artmaktadır. x doğrultusundaki hızın en büyük değerlerinin mahmuz etkisinden kurtulduğu kanal çıkış kesitinde elde edilmiştir. Mahmuzların ön ve arka yüzlerinde elde edilen hız profillerinden negatif hızların oluştuğu görülmekte ve bu negatif hızların oluştuğu bölge büyümektedir. Ayrıca, mahmuz yapısının hemen memba ve mansabında oluşan negatif hız değerlerinin ve kanal çıkış bölgesinde oluşan pozitif hız değerinin akımın debisinin artmasıyla arttığı belirlenmiştir. Kanal giriş bölgesinde ele alınan kesitte A1 ve B1 akım koşullarında akım alanının mahmuz yapısından etkilenmediği görülürken, akım debisinin diğer iki duruma göre arttığı C1 durumunda akım alanı üzerinde mahmuzların etkisinin bulunduğu görülmektedir. 


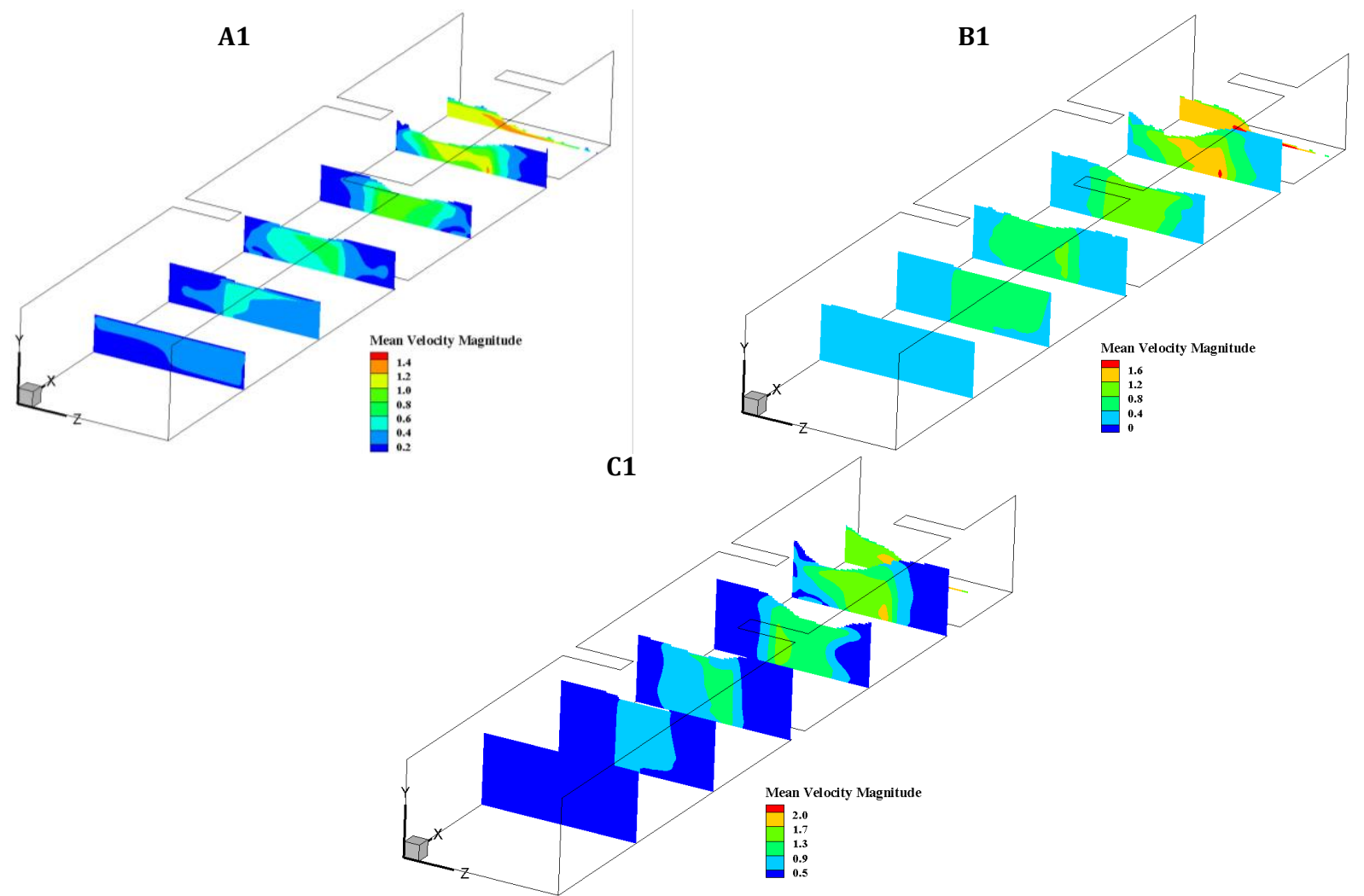

Şekil 9. Farklı akım durumlarında ortalama bileşke hız dağılımı (Mean velocity distribution in different flow conditions)
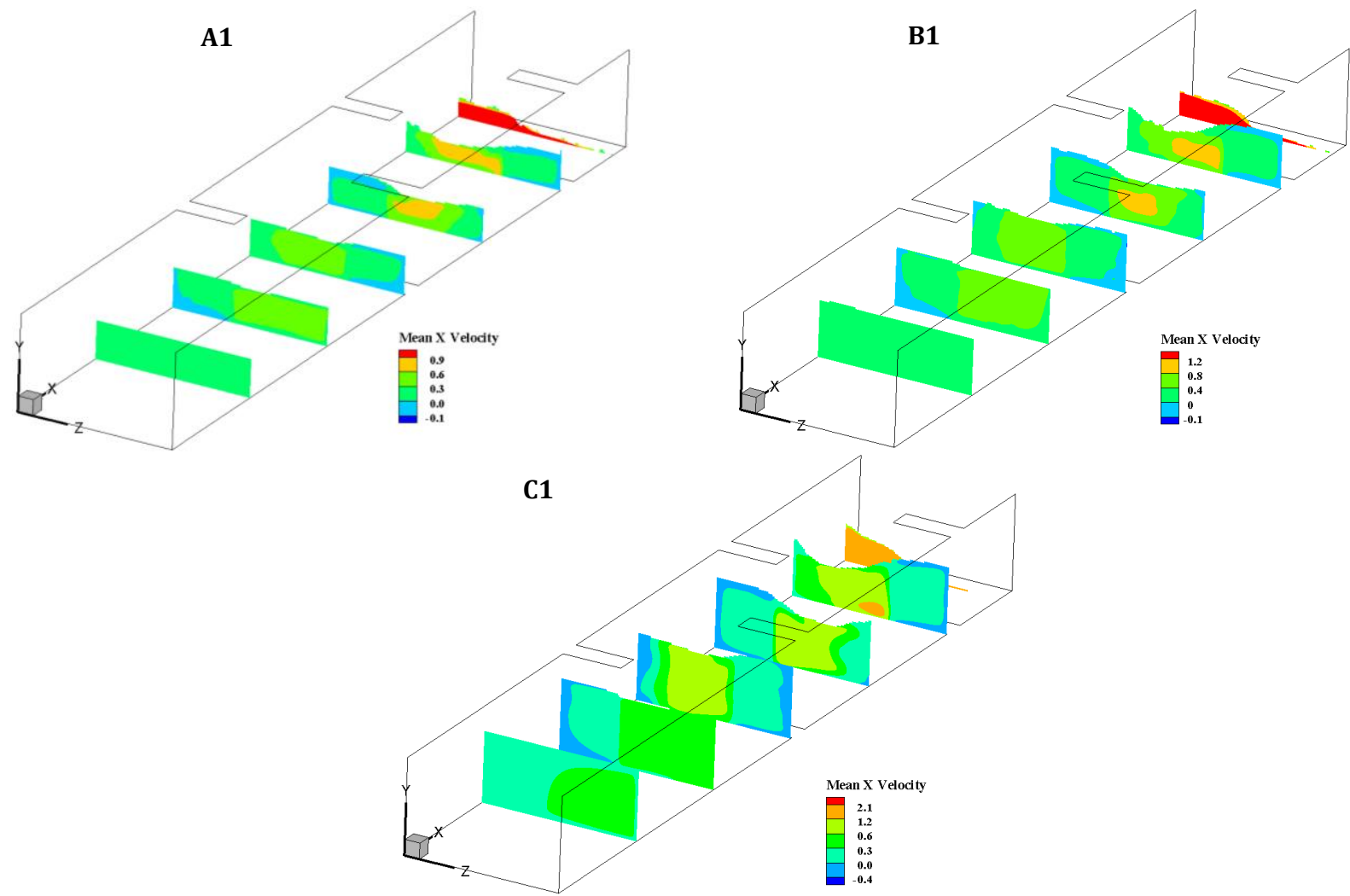

Şekil 10. Farklı akım durumlarında ortalama x yönlü hız bileșeni dağılımı (Mean x direction velocity distribution in different flow conditions)

Farklı akım durumlarında açık kanalın farklı kesitlerinde elde edilmiş y doğrultusundaki hız bileșenin ortalamasının dağılımı, Şekil 11'de görülmektedir. Verilen şekil incelendiğinde, mahmuzların membasındaki kesitlerde, mahmuzla etkileşimde olan bölgede y doğrultusundaki hız bileşeninin negatif yönlü oluştuğu görülürken, y doğrultusundaki hızın en büyük pozitif değerlerine mahmuz etkisinden dolayı daralan bölgede 
hızlanan akımın bir sonraki mahmuza yöneldiği bölgelerde ulaștığı söylenebilir. Ayrıca, negatif en büyük değere ise her üç akım koşulunda x doğrultusundaki ortalama hız bileşeninin maksimum kanal orta ekseninde sahip olduğu görülmektedir. Ayrıca, debinin artmasına paralel olarak, y doğrultusundaki ortalama hız bileşeninin pozitif olduğu bölgenin arttığı ve değerinin de büyüdüğü belirlenmiştir.
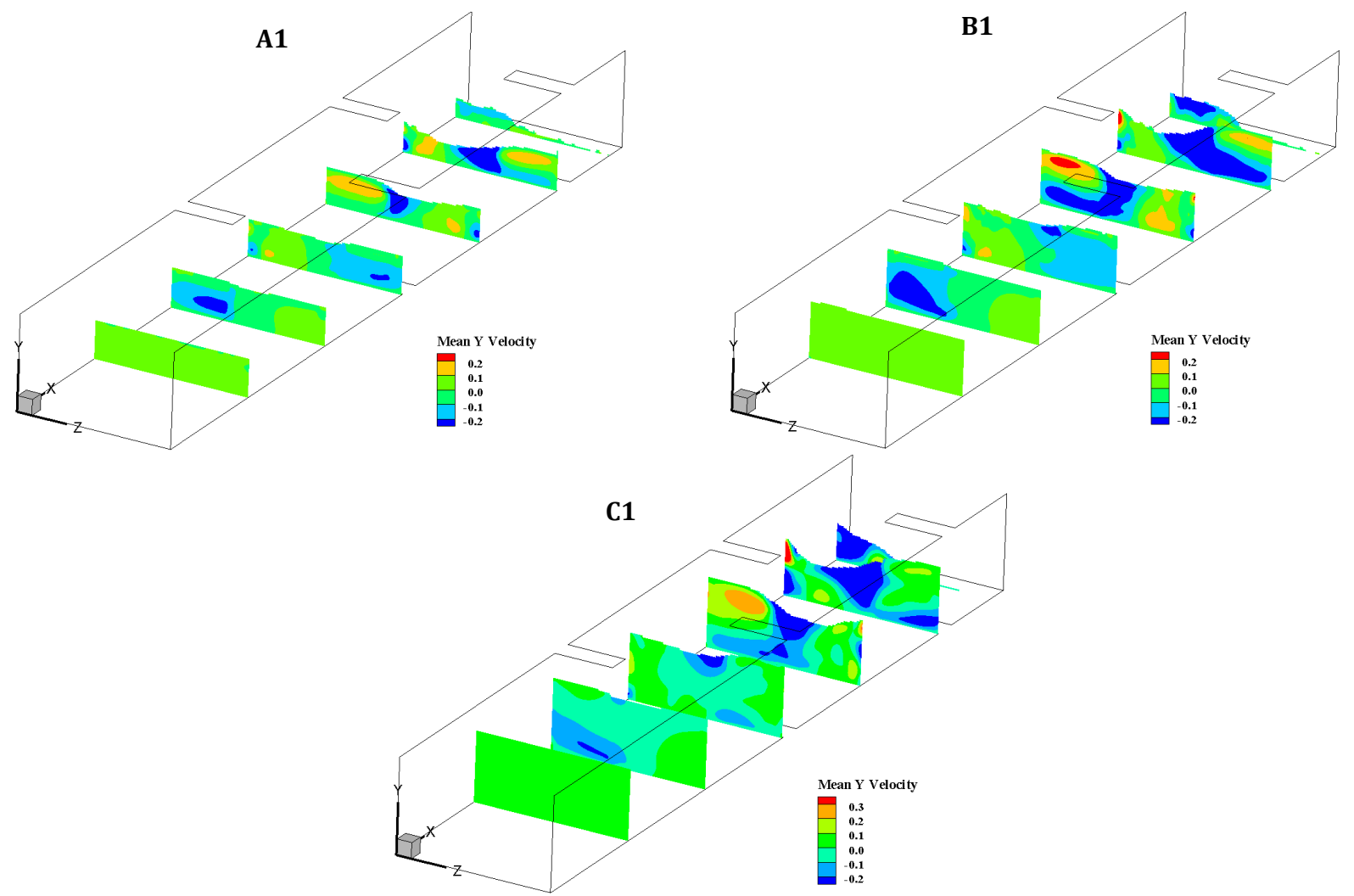

Şekil 11. Farklı akım durumlarında ortalama y yönlü hız bileşeni dağılımı (Mean y direction velocity distribution in different flow conditions)

\subsection{Basınç Dağılımı (Pressure Distribution)}

Șekil 12'de, farklı akım durumları için sayısal model sonucunda elde edilmiş ortalama basınç dağılımları verilmiştir. Debinin artmasıyla birlikte su derinliğinin artmasından kaynaklı olarak elde edilen basınç değerleri artmıştır. Kanal giriş bölgesine yakın bölgede elde edilen basınç dağılımında, tüm akım durumlarında bu kesitte hidrostatik basınç dağılımın oluştuğu görülmektedir. Akımın mahmuzlarla etkileşime girmesiyle birlikte hız alanında meydana gelen değişimden kaynaklı olarak, derinlik boyunca elde edilen basınç dağılımları hidrodinamik basınç dağılımına dönüşmektedir. Ayrıca, hız alanında meydana gelen eğriselliğe bağlı olarak mahmuz yapısının uç kısımlarında basınç değerlerinde dikkat çekici düzeyde azalma meydana gelmektedir. Bu azalma miktarı, debinin artmasıyla birlikte daha da artmaktadır. 


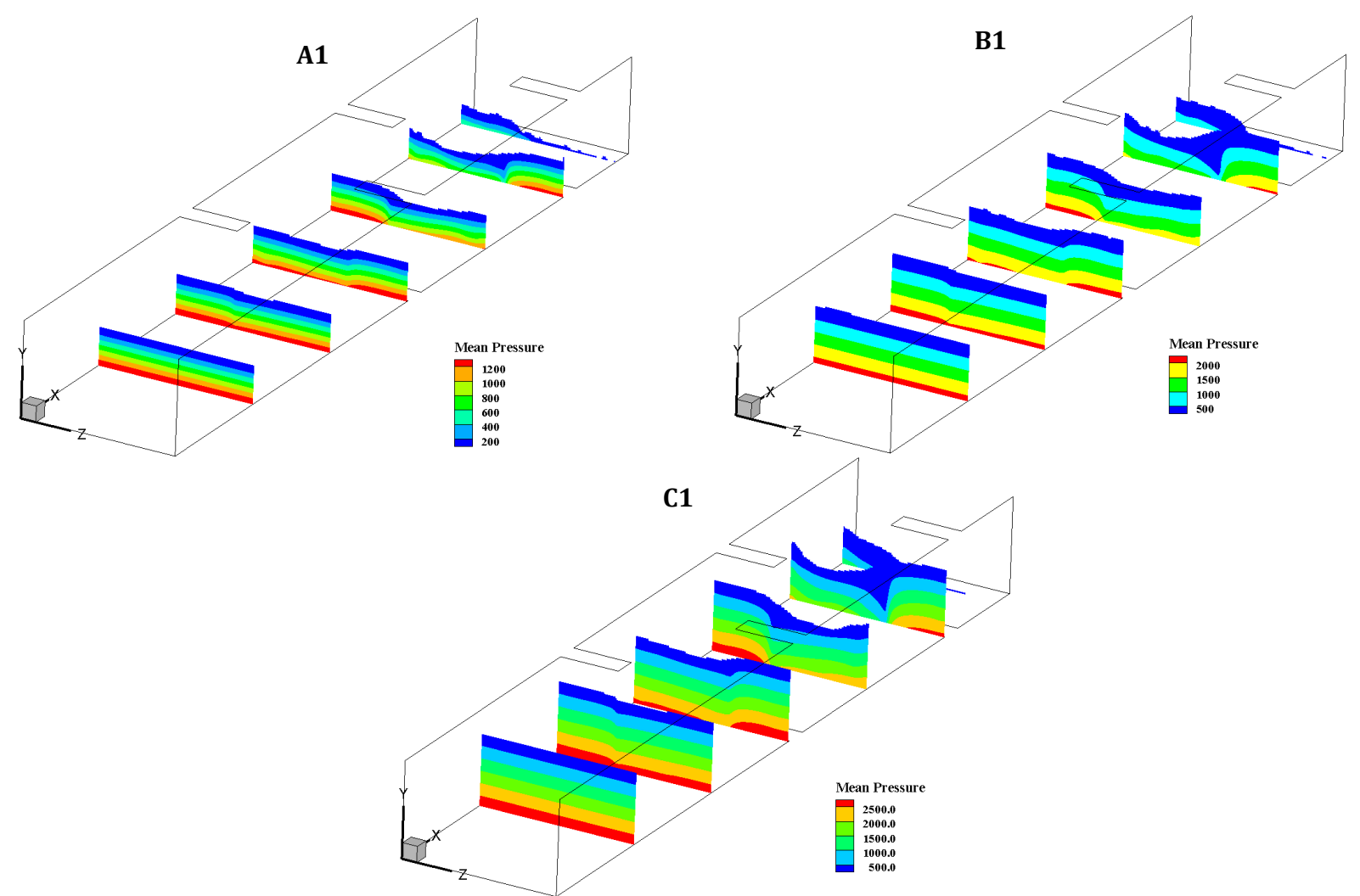

Şekil 12. Farklı akım durumlarında ortalama basınç dağılımı (Mean pressure distribution in different flow conditions)

\section{Sonuçlar (Conclusions)}

Mahmuzlar, akarsularda kıyının korunması, liman, balıkçı barınağı ve çekek yerlerinin giriș ve basen bölgelerinde sediment hareketinden kaynaklı sığlaşmayı önlemek adına inşa ediliriler. Bu çalışmada, kıyı koruma yapısı olarak oldukça farklı alanda uygulaması olan şaşırtmalı mahmuzlarla etkileşimde bulunan açık kanal akımının üç boyutlu sayısal modellemesi yapılmıştır. Sayısal modellemelerde sonlu hacimler yöntemine dayalı çözüm yapan ANSYS Fluent paket programı yardımıyla, akımı idare eden süreklilik ve momentum denklemleri, Reynolds Ortalamalı Navier Stokes (RANS) ve Büyük Girdap Simülasyon (LES) modelinin bir arada kullanıldığı DES modeliyle çözülmüștür. Serbest su yüzünün belirlenmesinde ise akışkan hacimleri yönteminden yararlanılmıștır. Farklı akım durumunda, deneysel ve sayısal olarak elde edilen su yüzü profillerinin karşılaștırılmasından, DES modelinin çalışmaya konu şaşırtmalı mahmuzlarla etkileşim halinde bulunan açık kanal akımı problemlerinin sayısal modellemesinde oldukça başarılı olduğu belirlenmiștir. Bunun yanında, debi değerinin artmasıyla deneysel ve sayısal su yüzü profilleri arasındaki uyumsuzluğun arttı̆̆ı görülmüştür. Deneysel olarak elde edilmemiş akım hız alanı $\mathrm{x}$, y ve z eksenlerinde olmak üzere farklı kesitlerde elde edilmiş ve mahmuzların tasarımında etkin olan basınç dağılımları değerlendirilmiştir. Akım hız alanının incelenmesinden, şaşırtmalı mahmuzların kuvvetli akımın kıyı bölgesine ulașmasına engel olduğu ve kıyı șeridinin mevcut yapısının korunmasının sağlandığı, akım alanının şaşırtmalı mahmuzlardan dolayı daraldığı bölgede büyük hızların oluştuğu, ayrıca mahmuzların ön ve arka bölgelerinde ayrılma bölgelerinin meydana geldiği görülmüștür. Basınç dağılımlarının incelenmesinden ise, debinin artmasıyla basınç değerlerinin arttığı ve mahmuzların ön yüzlerinde su derinliğinin artmasıyla bu bölgede en büyük basınç değerlerinin oluştuğu belirlenmiştir. Maddi olarak büyük yatırımlar gerektiren ve inşasından sonra değişikliğin oldukça masraflı olduğu bilinen mahmuzların tasarım aşamasında, ön tasarım ve farklı alternatiflerin denenmesi ve olası olumsuzlukların oluşumunun analizi ve önlenmesi konusunda sayısal modelleme yapılmasının büyük avantajlar sağlayacağı değerlendirilmektedir.

\section{Çıkar Çatışması (Conflict of Interest)}

Yazarlar tarafından herhangi bir çıkar çatışması beyan edilmemiştir. No conflict of interest was declared by the authors.

\section{Kaynaklar (References)}

Akoz, M. S., Gumus, V., Kirkgoz, M. S., 2014. Numerical Simulation of Flow over a Semicylinder Weir. Journal of Irrigation and Drainage Engineering, $140(6), 04014016$.

Akoz, M. S., Kirkgoz, M. S., Oner, A. A., 2009. Experimental and numerical modeling of a sluice gate flow. Journal of Hydraulic 
Research, 47(2), 167-176.

Aköz, M. S., Öner, A. A., Kırkgöz, M. S., 2007. Tabana yakın bir silindir etrafındaki akımın farklı türbülans modelleri ile sayısal modellenmesi. Çukurova Üniversitesi Mühendislik-Mimarlik Fakültesi Dergisi, 22(2), 107-117.

Aköz, M. S., Soydan, N. G., Şimşek, O., 2016. Kritik Üstü Açik Kanal Akiminin Detached Eddy Ve Large Eddy Simülasyon İle Sayisal Modellenmesi. Gazi Üniversitesi Fen Bilimleri Dergisi Part C: Tasarım ve Teknoloji, 4(4), 213-224.

ANSYS, 2012. FLUENT Theory Guide. USA: ANSYS Inc.

Aydin, M. C., 2012. CFD Simulation of Free-Surface Flow over Triangular Labyrinth Side Weir. Advances in Engineering Software, 45(1), 159-166.

Badiei, P., Kamphuis, J. W., and Hamilton, D. G., 1995. Physical experiments on the effects of groins on shore morphology. In Coastal Engineering, 1782-1796.

Barceló, F. R., 2014. Effect of porosity on hydrodynamic performance of Porous Bonded Revetments-numerical modelling and application for shore protection at Valencia, Spain. Master Thesis, 123 sayfa.

Gu, Z., Ikeda, S., 2009. Experimental study of open channel flow with groins. In Advances in Water Resources and Hydraulic Engineering, Berlin, Heidelberg, 1951-1956.

Gümüş, V., Şimşek, O., Soydan, N. G., Aköz, M. S., Kırkgöz, M. S., 2018. Akışkan Hacimleri Yöntemiyle Yapılan Sayısal Modellemelerde Yan Duvar Etkisinin İncelenmesi. Harran Üniversitesi Mühendislik Dergisi, 3(3), 15-21.

Hanson, H., Kraus, N. C., 1990. Shoreline response to a single transmissive detached breakwater. In Coastal Engineering, 20342046.

Hirt, C. W., Nichols, B. D., 1981. Volume of Fluid (VOF) Method for the Dynamics of Free Boundaries. Journal of Computational Physics, 39(1), 201-225.

İlkentapar, M., Öner, A., 2017. Geniş Başlıklı Savak Etrafındaki Akımın İncelenmesi. Niğde Ömer Halisdemir Üniversitesi Mühendislik Bilimleri Dergisi, 6 (2), 615-626.

Jesudhas, V., Roussinova, V., Balachandar, R., Barron, R., 2017. Submerged hydraulic jump study using DES. Journal of Hydraulic Engineering, 143(3), 04016091.

Jesudhas, V., Balachandar, R., Bolisetti, T., 2020. Numerical study of a symmetric submerged spatial hydraulic jump. Journal of Hydraulic Research, 58(2), 335-349.

Kirkgoz, M. S., Akoz, M. S., Oner, A. A., 2008. Experimental and Theoretical Analyses of Two-Dimensional Flows Upstream of Broad-Crested Weirs. Canadian Journal of Civil Engineering, 35(9), 975-986.

Kirkgoz, M. S., Akoz, M. S., Oner, A. A., 2009. Numerical Modeling of Flow over a Chute Spillway. Journal of Hydraulic Research, 47(6), 790-797.

Muslu, Y., 2001. Numerical Analysis for Lateral Weir Flow. Journal of Irrigation and Drainage Engineering, 127(4), 246-253.

Öner, A. A., 2009. Düzenli akıntı durumunda tabana oturan ve yarı gömülü eliptik bir silindir etrafındaki akımın sayısal incelenmesi. Gazi Üniversitesi Mühendislik Mimarlık Fakültesi Dergisi, 24(4), 575-582.

Özölçer, İ.H., 1998. Kıyı Korumasında Mahmuzların Etkilerinin Araştırılması. Doktora Tezi, Karadeniz Teknik Üniversitesi, Fen Bilimleri Enstitüsü, Trabzon.

Özölçer, İ.H., Kömürcü, M.İ., Birben, A.R., Yüksek, Ö. ve Karasu, S., 2006. Effects of T-Shape Groin Parameters on Beach Accretion. Ocean Engineering, 33, 382-403.

Rogallo, R. S., ve Moin, P., 1984. Numerical simulation of turbulent flows. Annual review of fluid mechanics, 16(1), 99-137.

Safie, O., Tominaga, A., 2020. Flow control by pile-group groynes used for riverbank instability management. In IOP Conference Series: Earth and Environmental Science, 511(1), 012002. IOP Publishing.

Şimşek, O., 2020a. Farklı Akım Koşullarına Sahip Açık Kanal Akımının Sayısal Modellemesi. Türk Doğa ve Fen Dergisi, 9(1), 91100.

Şimşek, O., 2020b. Üstten Akişli Kapak Akiminin Sayisal Modellemesi. Mühendislik Bilimleri ve Tasarım Dergisi, 8(3), 808-819.

Simsek, O., Akoz, M. S., Soydan, N. G., 2016. Numerical Validation of Open Channel Flow over a Curvilinear Broad-Crested Weir. Progress in Computational Fluid Dynamics, an International Journal, 16(6), 364-378.

Soydan Oksal, N. G., Akoz, M. S., Simsek, O., 2020. Numerical Modelling of Trapezoidal Weir Flow with RANS, LES and DES Models. Sadhana, 45(1), 91.

Soydan, N. G., Aköz, M. S., Şimşek, O., Gümüş, V., 2012. Trapez Kesitli Geniş Başlıklı Savak Akımının k-e Tabanlı Türbülans Modelleri ile Sayısal Modellenmesi. Çukurova Üniversitesi Mühendislik-Mimarlık Fakültesi Dergisi, 27(2), 47-58.

Soydan, N. G., Şimşek, O., Aköz, M. S., 2017. Prediction and Validation of Turbulent Flow around a Cylindrical Weir. European Water, 57, 85-92.

Süme, V., 2014. Grain size and beach formation characteristic at the t-head groins system at Kıyıcık, Turkey (Eastern Black Sea). Journal of Civil and Environmental Engineering, 4 (4), 1-5.

Süme, V., Yüksek, Ö., 2018. Investigation of shoaling of coastal fishery structures in the Eastern Black Sea coasts. Journal of the Faculty of Engineering and Architecture of Gazi University, 33(3), 843-852.

Süme, V., Yüksek, T., Kaya, A. 2019. Trabzon ve Rize kıyılarındaki T-mahmuzların plaj olarak kullanılabilirliği üzerine alan çalışması. Gümüşhane Üniversitesi Fen Bilimleri Enstitüsü Dergisi, 9(4), 610-619.

Yılmaz, B., 2003. Development and Validation of Two-Dimensional Depth-Averaged Free Surface Flow Solver, 101 sayfa, Middle East Technical University, Ankara. 